\title{
RHYNCHONELLIFORM BRACHIOPODS AND TRILOBITES OF THE ‘UPPER DARK INTERVAL' IN THE KONĚPRUSY AREA (DEVONIAN, EIFELIAN, KAČÁK EVENT; THE CZECH REPUBLIC)
}

\author{
MICHAL MERGL ${ }^{1, *}$, PETR BUDIL ${ }^{2}$ \\ 'Center of Biology, Geoscience and Environmental Education, Faculty of Education, University of West Bohemia in Plzeň, Klatovská 51, \\ 30619 Plzeň, the Czech Republic; e-mail: mmergl@cbg.zcu.cz. \\ ${ }^{2}$ Czech Geological Survey, Klárov 3/131, 11821 Praha 1, the Czech Republic; e-mail: budil@geology.cz. \\ ${ }^{*}$ corresponding author
}

Mergl, M., Budil, P. (2019): Rhynchonelliform brachiopods and trilobites of the 'upper dark interval' in the Koněprusy area (Devonian, Eifelian, Kačák Event; the Czech Republic). - Fossil Imprint, 75(1): 92-107, Praha. ISSN 2533-4050 (print), ISSN 2533-4069 (on-line).

\begin{abstract}
The dark pelbiodetrital limestone beds of the 'upper dark interval' in the Koněprusy area, Central Bohemia, the Czech Republic, the assumed manifestation of the Kačák Event in this area, yielded a moderately diverse faunule of rhynchonelliform brachiopods and trilobites. In total, 15 species have been recognized (13 brachiopods and 2 trilobites), but the majority of them are only tentatively determined to generic level due to fragmentation, rarity or poor preservation. Brachiopod genera Leptaenopyxis, Protodouvillina, Douvillinella, Holynetes, Poloniproductus, Iridistrophia, Mystrophora, Pentamerella, Quasidavidsonia, Carinatina, Mimatrypa, Leptathyris, Eoreticularia and a single trilobite Astycoryphe were determined. The mode of preservation indicates transport of skeletal bioclasts from shallower parts of the basin and their fragmentation in debris flows together with fragments of terrestrial plants, crinoid detritus and numerous pelagic fossils, especially the dacryoconarid Nowakia ex gr. otomari. Associated conodonts (as well as trilobites) indicate a late Eifelian age for the fauna (Polygnathus ensensis Zone).
\end{abstract}

Key words: Brachiopoda, Trilobita, Devonian, Eifelian, Kačák Event, Polygnathus ensensis Zone, Koněprusy, the Czech Republic

Received: March 11, 2019| Accepted: May 2, 2019 | Issued: August 29, 2019

\section{Introduction}

The 'dark interval' ('dark horizon', ‘upper dark interval', UDI) is an informal name used originally by Galle and Hladil (1991) for a $0.7 \mathrm{~m}$ thick interval of thin-bedded dark-grey pelbiodetrital limestone in the small abandoned Jirásek's Quarry near Koněprusy, Central Bohemia. This distinct dark interval above light grey Acanthopyge Limestone is known only from this locality and represents (together with the bed of lithoclastic breccia above) the youngest carbonate sediments in the Koněprusy area. The interval is correlated with the onset of the Kačák Event (Galle and Hladil 1991, Budil 1995). Fossils of the UDI were studied by Budil (1995), who noted the presence of dacryoconarid tentaculites, crinoids, brachiopods, foraminifers, trilobites and remains of terrestrial plants referred to Rellimia sp. New observations indicate the presence of fenestrate bryozoans, hyolithids and ostracods. The rich conodont fauna from this interval indicates a latest Eifelian age, Polygnathus ensensis Zone or Polygnathus eiflius Zone (Zikmundová and Kalvoda 1991, Kalvoda 1992, Hladil et al. 1993, Berkyová 2004, Vodrážková in prep.).
Dacryoconarid tentaculites were firstly determined by Pavel Lukeš (in Hladil et al. 1993, Budil 1995), who noted the presence of Nowakia (N.) ex gr. otomari BoučEK et PrAnTL, 1959. Nowakia (Cepanovakia?) cf. chlupacina AlBERTI, 1979 and Metastyliolina sp. Dacryoconarids were subsequently revised by Berkyová (2004), who recognized Nowakia (Cepanowakia) pumilio AlBerTI, 1978, Nowakia ex gr. otomari BoučEK et PRANTL, 1959, Styliolina ? fissurella (HALL, 1843), Lukesia elixi BerKYOVÁ, 2004 and ? Metastyliolina sp. Correlation of the UDI with the Kačák Member as assumed by Hladil et al. (1993) was not supported by Berkyová (2004) because specimens of $N$. ex gr. otomari from Jirásek’s Quarry differ in some morphological aspects from the specimens of $N$. otomari found elsewhere. The presence of fishes in the middle part of the UDI was already noted by Hladil et al. (1993). Mergl et al. (2017) observed abundant and diverse remains of vertebrates in the UDI, with acanthodes Nostolepis sp. and Cheiracanthoides sp. together with teeth of sarcopterygians. Organophosphatic brachiopods from the UDI are rare but remarkably diversified (Mergl 2019). Apart from the ubiquitous lower - middle Devonian genera Opsiconidion and 


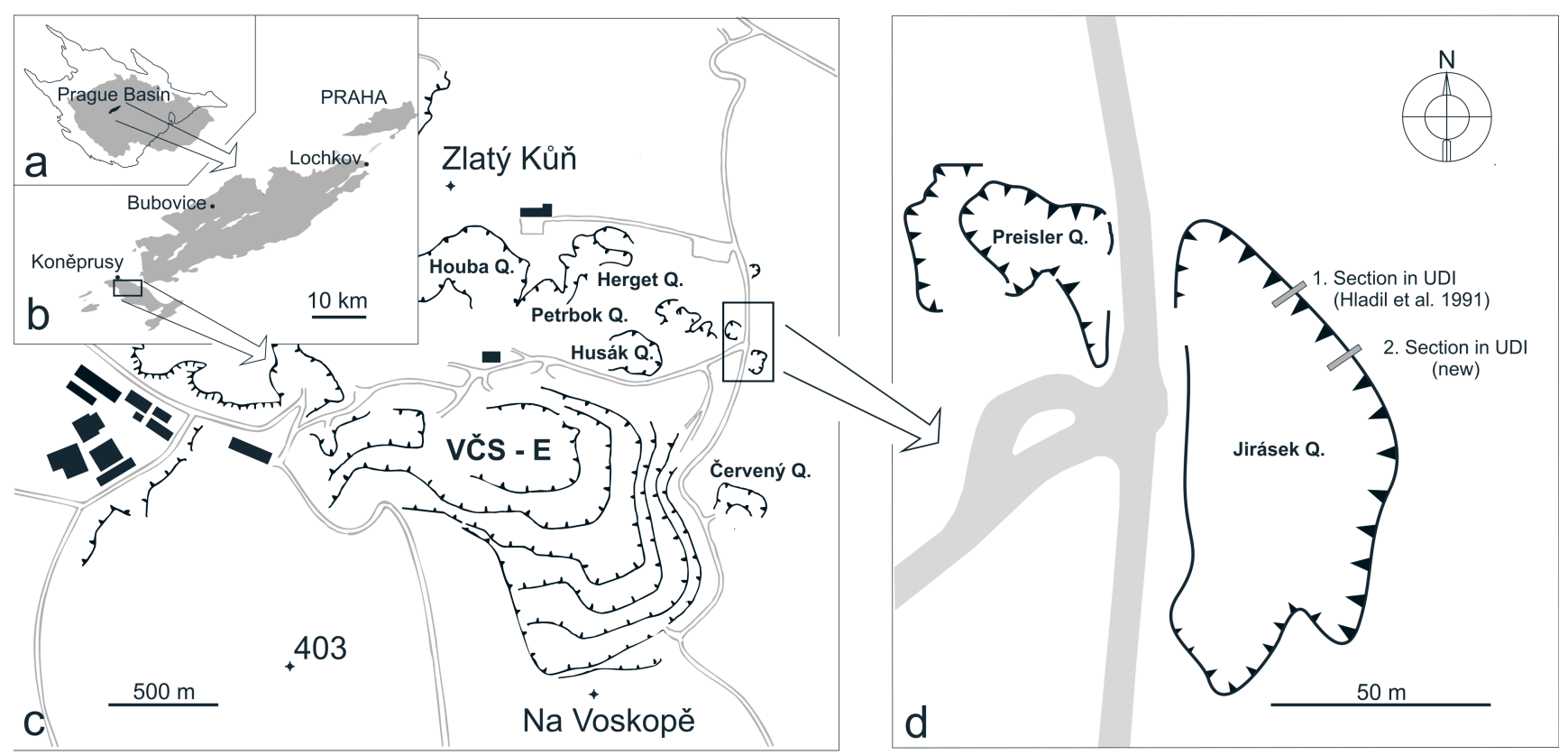

Text-fig. 1. Schematic maps showing location of the Prague Basin in the Barrandian area of the Czech Republic (a), the Koněprusy area (b), quarries in the Koněprusy area (c) and Jirásek's and Preisler's quarries (d). The exact location of the section described by Hladil et al. (1993) (1) and the new sections where the brachiopods were extracted (2) are figured. Abbreviations: UDI - upper dark interval, VČS-E - Velkolom Čertovy schody - východ quarry.

Opatrilkiella, the genera Lingulipora, Paterula and Orbaspina were determined, but the original diversity was much higher than could be assumed from the common minute fragments of discinoideans and linguloideans. The presence of chonetid and strophomenid brachiopods was reported by some authors (Hladil et al. 1993, Budil 1995) but the sampled material was poor in quantity and so far the only determination of brachiopods made by V. Havlíček (in Budil 1995) is dubious.

\section{Geological setting}

The Devonian of the Prague Basin continues from the underlying Silurian (Chlupáč 1998 and references therein). Resting on the Lochkovian to Emsian shallow-water reef complex, the shallow-water limestones of Eifelian age are restricted to a small area in the Koněprusy vicinity. Apart from the summit of Zlatý Kůn̆ Hill, the Acanthopyge Limestone and younger strata form a narrow strip between the entry to the Koněprusy Cave and Zadní Kobyla Hill. There are numerous abandoned small quarries, pits and small outcrops, but their stratigraphic correlation is not clear because of weak folding, faulting and by the cover of debris, soil and vegetation (Hladil et al. 1991, 1993). The most complete sequence of the upper part of the Acanthopyge Limestone is situated in the $\mathrm{N}$ wall of the abandoned Jirásek's Quarry (also known as the Acanthopyge Quarry) (Text-fig. 1). Above the Acanthopyge Limestone there follows a $0.7 \mathrm{~m}$ thick 'upper dark interval' covered by a $2.5 \mathrm{~m}$ thick sequence of limestone and shale beds which were referred to the Srbsko Formation (Givetian) by Hladil et al. (1993) (Text-figs 2, 3). The UDI is observable only in Jirásek's Quarry, but similar dark limestone infillings are known from neptunian dykes in the nearby quarry 'Na Voskopě' (Berkyová 2004).

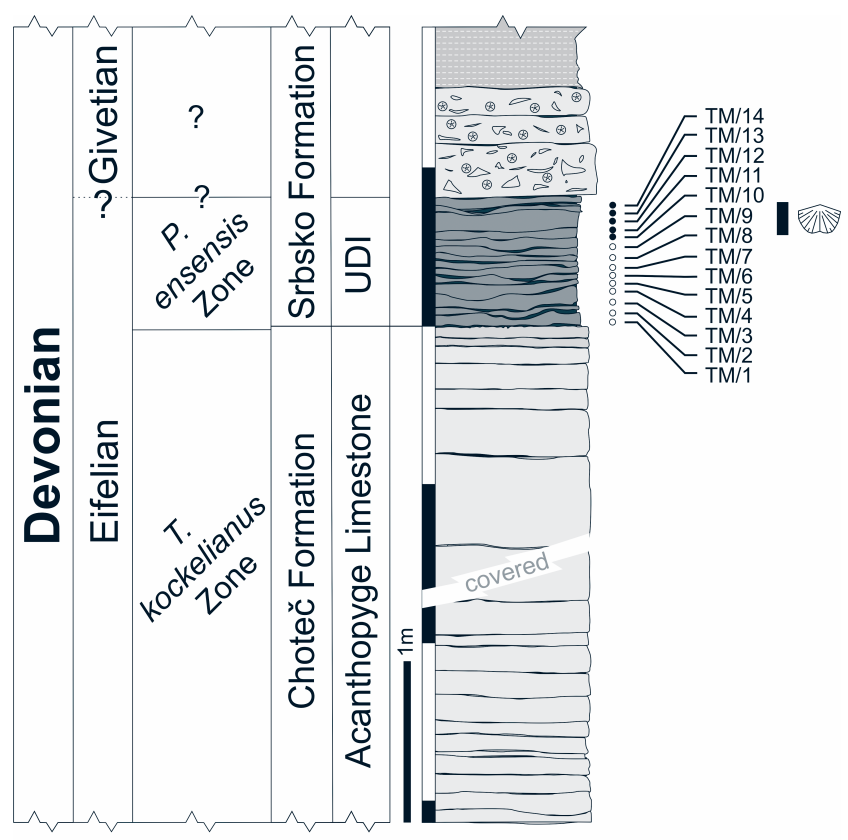

Light grey biodetrital limestone

Lithoclastic breccia

Dark grey pelbiodetrital limestone and calcareous shale

Shale

Text-fig. 2. Studied section in Jirásek's Quarry with essential data on lithology and samples studied on rhynchonelliform brachiopods and trilobites (black dots - productive, white dots - barren).

The Kačák Member of the Srbsko Formation is a 2 to $15 \mathrm{~m}$ thick unit of dark-grey thinly laminated calcareous shales and cherts (Svoboda and Prantl 1950, Budil 1995). The fauna shows a dominance of pelagic protozoans including 

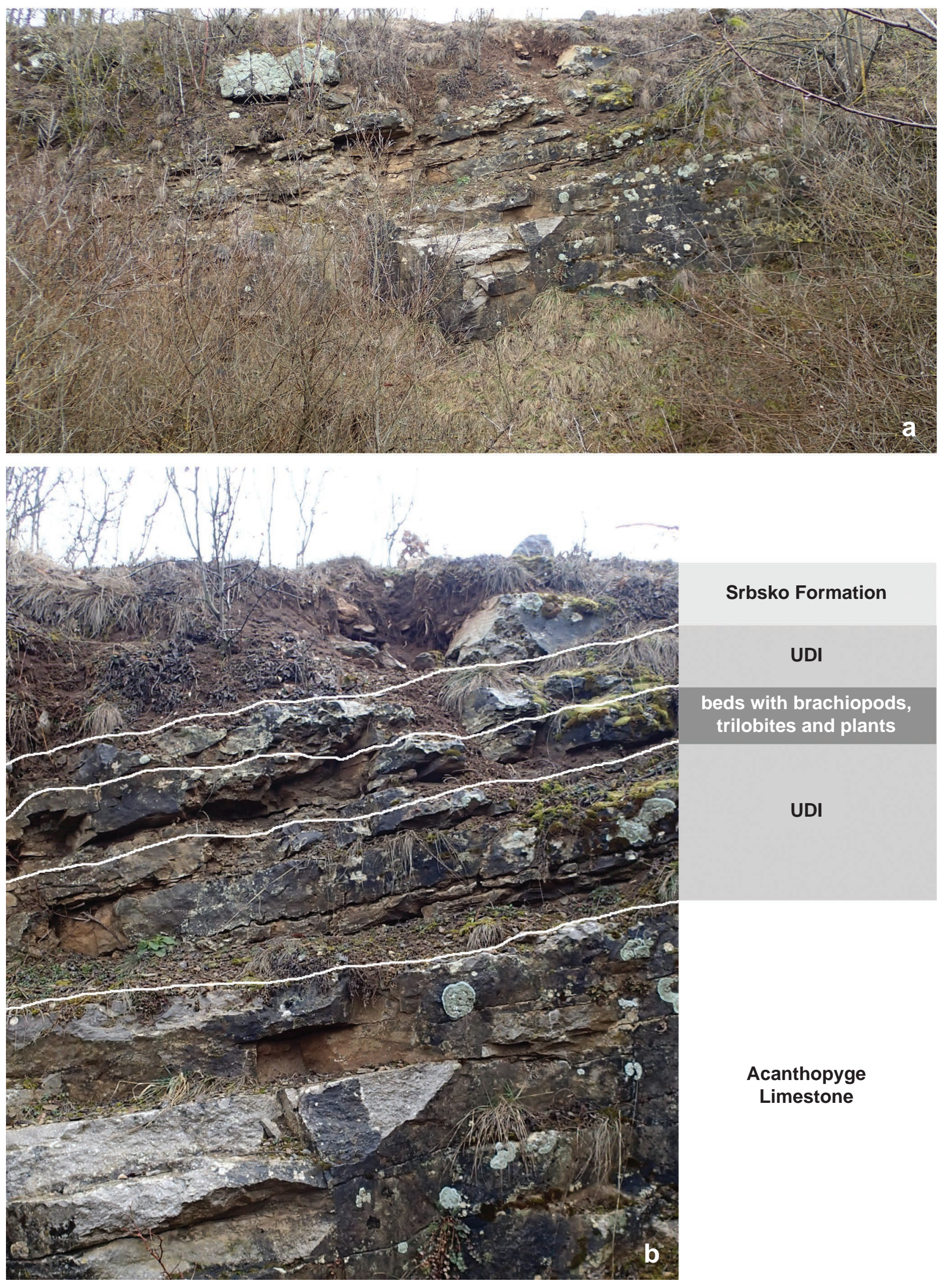

Text-fig. 3. Eastern wall of Jirásek's Quarry with studied section, with light-grey Acanthopyge Limestones in lower half of the wall, the UDI (in brown) in upper half followed by bioclastic breccia (Bed 46 sensu Hladil 1993) near the edge of the wall (a) and detail of UDI and adjacent limestones with the most productive beds (b). Photo January, 2019. 
radiolarians (Bouček 1964, Chlupáč and Turek 1983, Budil 1995) although relics of land plants are also frequent (Obrhel 1961, 1968). The Kačák Member is not typically developed in the Koněprusy area. Therefore, the UDI with abundant dacryoconarids and conodonts, poor benthic fauna and plant remains above the karstified beds of the Acanthopyge Limestone at Jirásek's Quarry section was assumed to be the time-equivalent of the Kačák Member by Hladil et al. (1991, 1993), Kalvoda (1992), Galle (1994) and Budil (1995). The UDI is followed by bioclastic breccia (Bed 46 sensu Hladil 1993) with tabulatomorphs and stromatoporoids, dominated by Caliapora ex gr. battersbyi. This species is typical for the Eifelian/Givetian boundary interval (Hladil 1993). Siltstones and shales above the breccia were tentatively referred to the Roblín Member of the Srbsko Formation by Hladil et al. (1991, 1993). The lithological character of the UDI, however, retains the main features of the Choteč Formation, e.g. carbonate sedimentation. Therefore, the UDI and bioclastic breccia above are still referred to the Acanthopyge Limestone facies (see Chlupáč 2003: 303), although chronostratigraphically they correspond to the Kačák Member of the Srbsko Formation.

\section{Material and methods}

All specimens of rhynchonelliform brachiopods and trilobites were sampled by hammering. Their remains are fairly common, but shell remains are often millimetre sized and featureless. Only some small-sized shells are complete or even articulated, but larger shells are always disarticulated, fragmented or with broken thinner parts of the shell. Intensive fragmentation is also distinct in other shells, noteworthy in shells of dacryoconarids, but without signs of abrasion. The mode of preservation indicates transport and intensive fragmentation of shells in the debris flow. Consequently, the quality of shells is not sufficient for precise taxonomic affiliation and the determination of some species has been only to generic level.

Fourteen samples from the UDI were tested for conodonts, organophosphatic brachiopods and dacryoconarids (Textfig. 2), but only the upper part of the sequence (samples TM 10 to TM 14) was more productive for rhynchonelliform brachiopod shells. Brachiopods from the bioclastic breccia bed above the UDI (Bed 46 sensu Hladil 1993) are not incorporated into the present work.

\section{Repository}

All specimens, including the types, are housed in the palaeontological collections of the Center of Biology, Geoscience and Environmental Education in the Faculty of Education at the University of West Bohemia in Plzen (PCZCU), the Czech Republic.

\section{Systematic palaeontology}

Phylum Brachiopoda DuméRIL, 1806

Subphylum Rhynchonelliformea Williams, Carlson, Brunton, Holmer et Popov, 1996

Class Strophomenata Williams Williams, Carlson, Brunton, Holmer et Popov, 1996

\author{
Order Strophomenida ÖPIK, 1934 \\ Superfamily Strophomenoidea KING, 1846 \\ Family Rafinesquinidae SchuCHERT, 1893 \\ Subfamily Leptaeninae Hall et Clarke, 1894
}

Genus Leptaenopyxis HaVLíčEK, 1963

Type species. Leptaena bouei Barrande, 1848; Praha Formation, Pragian; Bohemia, the Czech Republic.

Leptaenopyxis (?) sp.

Pl. 1, Fig. 5

M a t e ri a l. One ventral valve (PCZCU 2265).

Description. The shell is small, $6.6 \mathrm{~mm}$ wide and $3.5 \mathrm{~mm}$ long, transversely subrectangular, widest at the hinge line, with a few weak incomplete rugae on the flat disc. The folding of the shell along its periphery most likely represents the first entire ruga. The interior bears fine endospines.

Remarks. The shell apparently belonged to an immature individual lacking a geniculation and prominent concentric rugae which are characteristic for larger shells of leptaenids. The shell may belong to Leptaenopyxis irena (HAVLÍČEK, 1967). This species is rare in the Suchomasty Limestone of Emsian age (Havlíček and Kukal 1990) but the same or closely related but yet undescribed leptaenide occurs in the upper part of the Acanthopyge Limestone (Eifelian, Tortodus kockelianus Zone).

O c currence. UDI, sample TM 10.

Family Douvillinidae CASTER, 1939

Subfamily Protodouvillininae HARPER et Boucot, 1978

Genus Protodouvillina Harper et Boucot, 1978

Ty p e s p e ci es. Strophomena inaequistriata ConRAD, 1842; Hamilton Group, Eifelian; New York, USA

\section{Protodouvillina cf. interstrialis (PHILlIPS, 1841)}

\section{P1. 1, Figs 1-3}

1841 Orthis interstrialis, Leptaena interstrialis; Phillips, pp. 61, 62, pl. 25, fig. 103a-e.

2009 Protodouvillina interstrialis (PHILLIPS, 1841); Halamski, pp. 53, 54, pl. 3, figs 1-6, 8-17, 19, 20, 30-32, text-fig. 4.

2013 Protodouvillina interstrialis (PHILLIPS, 1841); Halamski and Baliński, pp. 281, 282, fig. 4A-F, L

[for complete synonymy see Halamski (2009) and Halamski and Baliński (2013)]

Material. Two incomplete ventral valves (PCZCU 2261, PCZCU 2263) and one shell fragment (PCZCU 2262).

De s c ripti o n. The unbroken ventral valve is $10 \mathrm{~mm}$ wide and $8.8 \mathrm{~mm}$ long, but another fragment (Pl. 1, Fig. 3) indicates a larger sized individual of this species. The ventral valve is thin-shelled, subsemicircular in outline, moderately convex in transverse and axial profiles. The maximum width is near the hinge line, cardinal extremities are subrectangular. The interior of the ventral valve has a small muscle field posteriorly divided by a weak ridge (Pl. 1, Fig. 1a). The entire inner surface is densely covered by fine uniformly sized endospines. Ornamentation is parvicostellate, in the ventral valve more strong costellae are separated by much broader interspaces with two to seven finer costellae. 
Remarks. The shell is assigned to Protodouvillina HARPER et Boucot, 1978 due to the typical parvicostellate ornamentation and moderate convexity of the ventral valve. Similarly shaped $P$. interstrialis (PhILliPs, 1841) is known from the Emsian to the Upper Devonian, with more or less evidenced occurrence in England, Belgium, Spain, Poland and the eastward extension towards the Ural Mts. and Afghanistan (Halamski 2009). To date, the species was not observed in the Barrandian area but newly presented material may belong to this species. This must be evidenced by a greater number of better preserved specimens.

O c currence. UDI, samples TM 10, TM 12.

\section{Genus Douvillinella Spriestersbach, 1925}

Ty p e s p e c i e s. Stropheodonta filifer Schmidt, 1913; Eifelian; Germany.

\section{Douvillinella sp.

$$
\text { Pl. 1, Fig. } 4
$$

Material. One incomplete dorsal valve (PCZCU 2264).

Description. The dorsal valve is flat, with an estimated $22 \mathrm{~mm}$ width, thin-walled. The cardinal process is of a stropheodontid type. Socket ridges are short, widely divergent, not joined by cardinal process lobes. Long thin dorsal side septa and a faint median ridge are present. Endospines are low, densely covering the visceral area. Ornamentation is multicostellate with straight costellae also on the posterolateral flanks.

R e m a r k s. The dorsal valve (Pl. 1, Fig. 4) is referred to Douvillinella on the basis of its interior and uniform ornamentation. Due to its multicostellate ornamentation, the shell differs from the associated fragments which have parvicostellate ornamentation and are herein referred to Protodouvillina cf. interstrialis (PHILLIPS, 1841).

O c currence. UDI, samples TM 10.

\section{Order Productida Sarytcheva et Sokolskaya, 1959 Suborder Chonetidina MuIR-Wood, 1955 \\ Family Anopliidae MuIR-Wood, 1962 Subfamily Holynetinae RACHEBOEUF, 1981}

\section{Genus Holynetes Havlíčé et Racheboeuf, 1979}

Type species. Holynetes holynensis HavLíčeK et Racheboeuf, 1979; Choteč Formation, Eifelian; Bohemia, the Czech Republic.

\section{Holynetes cf. holynensis Havlíček et Racheboeuf, 1979} Pl. 2, Figs 1, 2

Material. One incomplete dorsal valve (PCZCU 2272) and one ventral valve (PCZCU 2273).

Description. The shell is concavo-convex, thinshelled, rectimarginate, $3.2 \mathrm{~mm}$ wide in the larger specimen, with semicircular outline. The dorsal valve is deeply concave in axial profile and weakly concave in transverse profile, widest at the hinge line. The ventral valve is highly convex in axial profile and mound-like in transverse profile with flattened posterolateral corners. Hinge spines not seen.
Ornamentation consists of some 32 to 38 evenly sized and low rounded capillae. New capillae occasionally originate by bifurcation in the dorsal valve. Narrowly triangular posterolateral corners lack radial ornamentation and bear only very fine concentric growth lines.

Remarks. Only limited material is available and it lacks information about the internal features. Based on external morphology only, with some doubts, the shells are referred to Holynetes holynensis HAVLíčEK et RACHEBOEUF, 1979. However, the valves of $H$. holynensis described by Havlíček and Racheboeuf (1979) from the Choteč Formation (horizon with Pinacites jugleri; Nowakia sulcata Zone) are larger, from $6.5 \mathrm{~mm}$ to $7.7 \mathrm{~mm}$ in size and have more numerous capillae than the two shells sampled from the UDI.

O c currence. UDI, samples TM 12.

Suborder Productidina WAagen, 1883

Superfamily Linoproductoidea STEHLI, 1954

Family Monticuliferidae MuIR-Wood et CoOper, 1960

Subfamily Devonoproductinae

Muir-Wood et CoOper, 1960

\section{Genus Poloniproductus Biernat et Lazarev, 1988}

Ty p e s p e ci es. Productella varians Biernat, 1966; Skały Beds, Eifelian; Poland.

\section{Poloniproductus varians (BIERNAT 1966) P1. 1, Figs 6-11}

1896 Productella subaculeata var. angustior; Gürich, p. 217.

1896 Productella subaculeata var. latior; Gürich, p. 218.

1966 Productella varians n. sp.; Biernat, pp. 66-77, text-figs 19-21, pl. 11, figs 1-23, pl. 12, figs 1-16, pl. 13, figs 1-10.

1988 Poloniproductus varians (Biernat, 1966); Biernat and Lazarev, pp. 67-68, text-fig. 2, pl. 17, figs 1-5, pl. 17, figs 1-5, pl. 18, figs 1-4, pl. 19, figs 1-3, pl. 20, figs 1, 2.

2009 Poloniproductus varians (BIERnat, 1966); Halamski, pp. 67,68 .

2013 Poloniproductus varians (BIERnAT, 1966); Halamski and Baliński, p. 253, fig. 5.

[for complete synonymy see Halamski (2009) and Halamski and Baliński (2013)]

Material. Three ventral valves (PCZCU 2266, PCZCU 2268, PCZCU 2269a), two dorsal valves (PCZCU 2267, PCZCU 2294) and one juvenile dorsal valve (PCZCU 2270).

D e s c ri pti o n . The shell is deeply concavo-convex, with a thin-walled dorsal valve and much thicker ventral valve. The outline is transversely ovate. The largest entire shell is $8.5 \mathrm{~mm}$ wide and $6.0 \mathrm{~mm}$ long but fragments indicate slightly larger shell size.

The dorsal valve is deeply concave, with maximum concavity anteriorly, having flattened corners and a weakly concave posteroaxial part of the shell. The cardinal extremities are subrectangular, the maximum width lies at the posterior one-third. The interior is unknown except for the presence of fine endospines. Ornamentation of the dorsal valve consists of fine concentric growth lines arranged ca. $0.1 \mathrm{~mm}$ apart having a somewhat wavy course. These lines change to coarse rugellae near the hinge line. Shallow 
imperfectly bordered large pits covering the dorsal surface have the same spacing as the spines on the opposite (ventral) valve.

The ventral valve is highly convex in transverse and axial profiles, with flattened posterolateral corners. The beak is prominent, with asymmetric cicatrix, shortly overturned above the hinge lines. The interior has densely evenly spaced pustules. Ornamentation of the ventral valve consists of evenly spaced fairly coarse thick-walled suberect spines. Proximal parts of the spines are distinctly curved. The entire spine length is unknown. Concentric ornamentation consists of fine growth lines having a wavy course around the base of the spines. Lines closer to the hinge lines are coarser, forming short rugellae. Radial ornamentation is absent.

R e m a r k s. The disarticulated valves found in the UDI of the Srbsko Formation clearly resemble externally those of Poloniproductus varians (BIERNAT, 1966) which is an abundant productid of the Skaky Beds of the Holy Cross Mountains (Biernat 1966, Biernat and Lazarev 1988). The only difference is the smaller size of specimens from the UDI, but they most likely represent immature individuals.

Occurrence. UDI, samples TM 10, TM 11, TM 12; outside Bohemia, the species is known from the Upper Eifelian (Skały Beds) to Lower Givetian of the Łysogóry region of the Holy Cross Mountains, Poland (Biernat and Lazarev 1988, Halamski 2009), and from the Upper Eifelian to Lower Givetian of eastern Anti-Atlas, Morocco (Halamski and Baliński 2013).

\section{Order Orthotetida WAAGEN, 1884 \\ Suborder Orthotetidina WAAGEN, 1884 \\ Superfamily Chilidiopsoidea Вочсот, 1959 \\ Family Chilidiopsidae Boucot, 1959 \\ Subfamily Chilidiopsinae Boucoт, 1959}

\section{Genus Iridistrophia HAVLÍČEK, 1967}

Type species. Orthis umbella Barrande, 1848; Lochkov Formation, Lochkovian; Bohemia, the Czech Republic.

\section{Iridistrophia sp. \\ Pl. 1, Figs 12, 13}

Material. Two ventral valves (PCZCU 2269b, PCZCU 2271).

$\mathrm{D}$ e s c ripti on. The ventral valve is moderate in size, $15 \mathrm{~mm}$ wide and $11.5 \mathrm{~mm}$ long, weakly convex in transverse and axial profiles, thin-walled relative to shell size, widest at the hinge line. Ornamentation is parvicostellate, with 12 straight primary costellae originating at the umbo. The costellae do not branch and gently increase in size anteriorly. New costellae originate exclusively by intercalation and rapidly attain the size of primary costellae. Interspaces are wider than the costellae. Their floors are covered by fine concentric fila of subequal size (Pl. 1, Fig. 12b, c). The costellae crests are not crenulated. Anteromedianly, there are 10-11 costellae per $5 \mathrm{~mm}$. Shell substance is impunctate.

Remarks. The preserved shell is slightly deformed having partly broken flanks. Therefore it is not clear whether the deviation from bilateral symmetry is original or caused by fossilization. The shell resembles the moderate-sized specimen of Xystostrophia umbraculum (vON SCHLOTHEIM, 1820), but costellae on the latter are crenulated even in small specimens. Iridistrophia HAvLíčEK, 1967 is known from the Lochkovian to Lower Eifelian (Jansen 2001) but Halamski (2009) and Halamski and Baliński (2013) referred Iridistrophia undifera (SCHNUR, 1854) from the Upper Eifelian of Germany, Poland and Morocco to this genus. The shell is similarly shaped to Schuchertella GIRTY, 1904 but this genus has an extropunctate shell. The small specimen with triangular ventral muscle field (Pl. 1, Fig. 13) bordered by widely divergent dental plates may belong to the same species.

O c currence. UDI, sample TM 12.

Order Orthida SchucherT et COOPER, 1932

Suborder Dalmanellidina Moore, 1952

Superfamily Dalmanelloidea SchuChERT, 1913

Family Mystrophoridae SCHuCherT et CoOPER, 1931

Genus Mystrophora KAYSER, 1871

Type species. Orthis areola Quenstedt, 1871; Eifelian; Germany.

\section{Mystrophora sp. \\ P1. 2, Fig. 3}

M a te ri a 1. One dorsal valve (PCZCU 2274).

Description. The dorsal valve is $6 \mathrm{~mm}$ wide, transversely oval, with a deep wide sulcus and obtuse cardinal extremities. Ornamentation is formed by fine bifurcate radial costellae, 30-35 along the anterior margin of the valve.

Remarks. Despite its poor preservation, the valve is referred to Mystrophora KAYSER, 1871 due to its size, outline, presence of sulcus and form of ornamentation. More material is required to assess its relationship to $M$. areola QuENSTEDT, 1871 which is known from the Eifelian of Germany and Burma (Anderson et al. 1969).

O c c urre n c e. UDI, sample TM 12.

Order Pentamerida Schuchert et Cooper, 1931 Suborder Pentameridina Schuchert et CoOper, 1931

Superfamily Clorindoidea Rzhonsnitskaya, 1956

Family Clorindidae Rzhonsnitskaya, 1956

Subfamily Pentamerellinae SAPELNIKov, 1973

Genus Pentamerella HaLl, 1867

Type species. Atrypa arata Conrad, 1841; Schoharie Formation; New York, USA.

\section{Pentamerella sp.}

P1. 2, Figs 4, 5

M a te ri a l. One dorsal valve (PCZCU 2275) and one ventral valve (PCZCZU 2276).

Description. The shell is thick walled, strongly biconvex, $5 \mathrm{~mm}$ wide, most likely rectimarginate. The dorsal valve is transversely oval, with a length $80 \%$ of the width and widest in the posterior one-third region. 
Maximum convexity is in the posterior one-third. Posterior corners are rounded, slightly flattened. The ventral valve is subpentagonal, more elongate, strongly convex in posterior third. Ornamentation is formed by ten strong costae in the dorsal valve and nine costae in the ventral valve. The costae are weakly defined at the beaks, but progressively increase anteriorly. There are three coarser median costae in the dorsal valve and two coarser costae in the ventral valve compared to those on the flanks.

Remarks. The shells are referred to Pentamerella HALl, 1867 due to their small size, thick shell and coarse costae, but lack of data about the interior makes this affiliation only tentative. The specimens may be related to some yet undescribed small pentamerid which is present in the upper part of the Acanthopyge Limestone (Eifelian, Tortodus kockelianus Zone) in the Koněprusy area.

O c c urrence. UDI, samples TM 10, TM 12.

\section{Order Atrypida Rzhonsnitskaya, 1960 \\ Suborder Davidsoniidina COPPER, 1996 \\ Superfamily Davidsonioidea KING, 1850 \\ Family Davidsoniidae KING, 1850}

Genus Quasidavidsonia HAVLíčEK, 1987

Type species. Prodavidsonia vicina HavlíčeK, 1967; Choteč Formation, Eifelian; Bohemia, the Czech Republic.

\section{Quasidavidsonia mediocarinata (HAVLÍČEK, 1967)}

$$
\text { Pl. 2, Fig. } 15
$$

1967 Prodavidsonia mediocarinata sp. n.; Havlíček, p. 215, pl. 49, figs 10-14.

1990 Quasidavidsonia mediocarinata (HAVLíčEK, 1967); Havlíček and Kukal, p. 166, pl. 3, figs 11-15.

M a t e ri a 1. One dorsal valve (PCZCU 2285).

De s cription. The valve is $12 \mathrm{~mm}$ wide and $8.5 \mathrm{~mm}$ long, with a thick shell-wall. The dorsal valve is semicircular, weakly convex in transverse profile and moderately convex in axial profile, with a narrow shallow sulcus and flattened posterolateral corners.

Re marks. A single poorly preserved dorsal valve is known from the UDI. Its size and profile is consistent with affiliation to Q. mediacarinata HAVLÍČEK, 1967. This is a common species in the Acanthopyge Limestone (Havlíček and Kukal 1990), but the genus ranges from the Emsian to the upper Givetian.

O c c urre n c e. UDI, sample TM 12.

\section{Family Carinatinidae RzHONSNITSKaya, 1960}

\section{Genus Carinatina Nalivkin, 1930}

Type species. Orthis arimaspus EICHwald in von Buch, 1840; Middle Devonia; Russia.

\section{Carinatina arimaspus (EICHWALD in VON BUCH, 1840)}

$$
\text { P1. 2, Figs 8, 9, } 14
$$

1840 Orthis Arimaspus EIchw.; von Buch, pp. 108, 112.

1975 Carinatina arimaspus (EICHWALD, 1840); Rzhonsnitskaya, p. 139 , text-fig. 45 , pl. 31, figs 1-3, 12 .
1978 Carinatina arimaspus (EICHWALD, in Buch 1840); Copper, p. 310 , pl. 7 , figs $1-6$.

1987 Carinatina arimaspus (EICHWALD, 1840); Havlíček, p. 93, pl. 11, figs 7-9.

1990 Carinatina arimaspus (EICHWALD, 1840); Havlíček and Kukal, pp. 165, 166, pl. 17, fig. 9, pl. 23, fig. 4.

$\mathrm{M}$ aterial. Three incomplete ventral valves (PCZCU 2279, PCZCU 2280, PCZCU 2293).

Description. The ventral valve is carinate, moderate thick walled and bears laterally curved rounded coarse costae. New costae originate by both bifurcation and intercalation. The shell surface is covered by faint concentric growth fila at regular, ca. $0.3 \mathrm{~mm}$, intervals (Pl. 2, Fig. 14). The secondary shell layer is distinctly fibrous.

R e m a r ks. Although strongly fragmented and poorly preserved, the size, moderately thick shell, form of radial ornamentation and carinate ventral valve justify assignment of these valves to Carinatina arimaspus (EICHWALD in von $\mathrm{BuCH}, 1840)$. Although rare, this species is present in the Acanthopyge Limestone (Havlíček and Kukal 1990), and a similar mode of preservation indicates that fragments from the UDI likely belong to this geographically widespread and phenotypically variable species from the Emsian (Khodalevich et al. 1959, Halamski and Baliński 2013).

O c c urre n c e. UDI, sample TM 10, TM 12.

\section{Carinatina ? sp.}

P1. 2, Figs 6, 7, 18

Material. Three incomplete dorsal valves (figured PCZCU 2277, PCZCU 2278) and one small complete shell preserved as external moulds (PCZCU 2288).

Description. The shell is small, ventri-biconvex, subcircular, $5 \mathrm{~mm}$ wide, with carinate ventral and sulcate dorsal valve, and with a moderately thick wall. The dorsal valve has 13 to 15 rounded undivided ribs slightly curved laterally. Microornamentation consists of fine growth fila.

$\mathrm{Re} \mathrm{m}$ arks. The shell is similar to fragments referred to Carinatina arimaspus which is present in the UDI but differs in its finer ribbing.

O c c urre n c e. UDI, sample TM 10, TM 12.

Family Karpinskiidae Poulsen, 1943

Subfamily Karpinskiinae Poulsen, 1943

Genus Mimatrypa Struve, 1964

Ty p e s p e ci es. Terebratula flabellata Roemer, 1844; Eifelian; Germany.

\section{Mimatrypa (?) sp.}

Pl. 2, Fig. 10

M a t e ri a l. Ventral (?) valve (PCZCU 2281).

Description. One smooth and poorly preserved flattened ventral (?) valve covered by 24 rounded simple evenly sized costae separated by evenly sized interspaces, all covered by fine concentric lines. The outline of the valve is slightly transverse, with obtuse cardinal extremities. Shell substance is impunctate. 
$\mathrm{R} \mathrm{e} \mathrm{marks}$. The valve is similar to the small ventral valve of Mimatrypa Struve, 1964 in its undivided fine ribs but this determination is somewhat speculative. The valve resembles a minute shell of Tropidoleptus HaLl, 1857 , but small individuals of this enigmatic genus are less transverse and have an endopunctate shell substance (Harper et al. 2010). Costae on the flanks of specimen Mimatrypa (?) sp. are more prominent with smaller ones on the axial part, but in Tropidoleptus the sizes of costae decrease laterally.

O c c urren ce. UDI, sample TM 10.

\section{Order Athyridida Boucot, Johnson et Staton, 1964 Suborder Athyrididina Boucot, Johnson et Staton, 1964 \\ Superfamily Athyridoidea DAVIDSON, 1881 \\ Family Athyrididae DAVIDSON, 1881 \\ Subfamily Didymothyridinae Modzalevskaya, 1979}

\section{Genus Leptathyris SIEHL, 1962}

Type species. Leptathyris gryphis SieHL, 1962; Eifelian; Rhineland, Germany.

\section{Leptathyris sp.}

Pl. 2, Figs 11-13

Material. Two figured complete shells (PCZCU 2283, PCZCU 2284), one ventral valve (PCZCU 2282) and several unfigured mostly incomplete dorsal and ventral valves.

Description. The shell is biconvex, thin-walled, rectimarginate, small, with a maximum width of $3.3 \mathrm{~mm}$. The shell substance is impunctate. The dorsal valve is subcircular, with a short beak, lenticular in transverse and axial profiles, with evenly rounded margins. The ventral valve has similar convexity but has an erect posteriorly extended beak with low apsacline palintrope.

$\mathrm{R} \mathrm{e} \mathrm{m} \mathrm{a} \mathrm{r} \mathrm{k} \mathrm{s.} \mathrm{This} \mathrm{species} \mathrm{is} \mathrm{the} \mathrm{commonest} \mathrm{brachiopod}$ in the UDI. Three articulated specimens were observed, but their interior is unknown. Leptathyris gryphis SIEHL, 1962 from the Greifenstein Limestone (Eifelian) of Rhineland differs by the shallow sulcus in both valves. Leptathyris deino HAVLíčEK, 1990 (in Havlíček and Kukal 1990) from the Suchomasty Limestone (Emsian) is similar in its rectimarginate commissure but is much larger than specimens observed in the UDI. In terms of shape and smooth outer surface, the shell is also similar to Leptathyris circula (WALCOTT, 1884), a common species from the Eifelian of Nevada (Johnson 1966), but differs in its rectimarginate anterior commissure. Externally, the shell is similar to Eobiernatella BALIŃSKI, 1995 from the Givetian and Frasnian of Poland and Russia in its rectimarginate commissure and absence of a sulcus.

O c currence. UDI, sample TM 12.

\author{
Order Spiriferida WAAGEN, 1883 \\ Suborder Delthyridina PhILliPs, 1841 \\ Superfamily Reticularioidea WAAGEN, 1883 \\ Family Reticulariidae WAAGEN, 1883 \\ Subfamily Eoreticulariinae GourvenNec, 1994
}

\section{Genus Eoreticularia NALIVKIN in FrederIKs, 1924}

Ty p e s p e ci e s. Spirifer indifferens BARRANDE, 1848; Emsian; Bohemia, the Czech Republic.

\section{Eoreticularia ? sp. \\ Pl. 2, Figs 16, 17}

Material. Two incomplete dorsal valves (PCZCU 2286, PCZCU 2287).

Description. The dorsal valve is thin-walled, transversally elliptical, $14 \mathrm{~mm}$ wide, widest at about midlength, moderately convex in axial profile and weakly and evenly convex in transverse profile, without any distinct sign of a fold or sulcus. The apex is blunt and rounded. Thin median septum and a pair of gently divergent ridges are observable on the valve interior. The shell exterior lacks distinct macroornament, but traces of short granules or spines in concentric and radial rows were observed.

$\mathrm{R} \mathrm{e} \mathrm{m} \mathrm{a} \mathrm{r} \mathrm{k} \mathrm{s.} \mathrm{The} \mathrm{material} \mathrm{is} \mathrm{badly} \mathrm{preserved} \mathrm{and} \mathrm{an} \mathrm{only}$ approximate determination is possible. Lack of a distinct dorsal fold, presence of thin median septum, finely spinose or granulose microornamentation, convexity and outline are consistent with Eoreticularia NALIVKIN in FrederIKS, 1924 or other related genera.

O c curren ce. UDI, sample TM 12.

Phylum Arthropoda von SiEBoLd, 1848

Subphylum Trilobitomorpha STøRMER, 1944

Class Trilobita WALCH, 1771

Order Proetida Fortey et Owens, 1975

Family Tropidocoryphidae PřıBYL, 1946

Subfamily Tropidocoryphinae PřIBYL, 1946

Genus Astycoryphe Richter et Richter, 1919

Type species. Astycoryphe senckenbergiana Richter et Richter, 1919; Eifelian; Germany.

\section{Astycoryphe tureki sp. nov.}

Pl. 2, Figs 19-21

H o l o t y pe. Incomplete cranidium with exoskeleton, PCZCU 2290, figured on Pl. 2, Fig. 21.

$\mathrm{P}$ a r a ty $\mathrm{p}$ e. Isolated librigena, PCZCU 2289, figured on Pl. 2, Fig. 20.

Other material. Fragment of thoracic segment (PCZU 2292) from type locality and horizon can be questionably affiliated to this species.

Ty p e 1 o c a lity. Koněprusy, Jirásek’s Quarry, sample TM 12.

Type horizon. Uppermost part of the Acanthopyge Limestone, UDI (Eifelian/Givetian boundary interval), Polygnathus ensensis Zone with Nowakia ex gr. otomari.

Diagnosis. Astycoryphe, which is closely related to Astycoryphe exilis van VIERSEN et Prescher, 2010 with respect to these specific characters: marginal rim with three terrace lines sub-parallel with the border; outline of glabella wider (tr.), more pear-like posteriorly; S1-S3 only inconspicuously impressed, perceptible especially by effacing of generally much more prominent sculpture 
consisting of randomly arranged terrace lines (distinct especially posterolaterally). Fine pits randomly scattered on the preglabellar field are less numerous but more perceptible; these are missing on L1 and L2 and on the adaxial part of the palpebral lobes. Posterior border furrow on librigena is less sharply bent posteriorly.

Description. The cranidium is only moderately vaulted. The anterior contour of the cranidium is broadly rounded. The anterior border is strongly vaulted, narrow, bearing three well-defined, border-parallel terrace ridges. The glabella is well-demarcated anteriorly and laterally by deep furrows, anterior to S0 it broadens slightly between the front and S2, strongly between S2 and S1, and slightly between $\mathrm{S} 1$ and deep $\mathrm{S} 0 . \beta$ is positioned further abaxially than $\delta ; \delta$ is positioned opposite $\mathrm{S} 1$. S0 is narrow, deepens abaxially. S1 and S2 are only slightly impressed; L1 and L2 are poorly defined. S3 is almost indiscernible. The entire glabella and palpebral lobes are covered with randomly oriented prominent terrace ridges that are distinctly inflated especially posterolaterally. The occipital ring is not preserved. Preglabellar and librigenal fields are slightly more downward sloped outside of the well-developed tropidium, represented by one ridge only. The lateral and posterior borders are strongly vaulted. The proximal part of genal spine is robust, wide, and the posterior border furrow is arched. The librigenal field is devoid of ornamentation.

Remarks. Astycoryphe tureki sp. nov. appears to be closely related to $A$. exilis vAN VIERSEN et PrESCHER, 2010 from the upper Eifelian of Ardennes (lower part of the Hanonet Formation). Both species share the general configuration of the cranidium, especially very moderate vaulting of the glabella, characteristic pits on the preglabellar field and its vaulting in sag. cross-section. Both species also share minute dimensions and, furthermore, their stratigraphical occurrence in the uppermost Eifelian. Both species differs by features mentioned in differential diagnosis. Astycoryphe tureki sp. nov. shares, however, some features also with $A$. jorusi van Viersen et Prescher, 2010, also from the upper Eifelian of Ardennes (lower part of the Hanonet Formation). These include in particular the glabella outline and less prominent S1-S2, as well as shape of the free cheeks with robust base of genal spine and the course of the anterolateral and posterior border furrows. The two species differ, however, in their different ornamentation and presence of pits on the preglabellar field in the new species. As A. jorusi occurs in the same stratigraphical interval (uppermost Eifelian), it probably forms a group of species including $A$. exilis and $A$. tureki - possibly belonging to the latest representatives of the Astycoryphe evolutionary lineage which was terminated by the Taghanic Event (see Feist 2003: 433). The poorly preserved cephalon of the holotype specimen of the type species, Astycoryphe senckenbergiana RichteR et RichteR, 1919 (figured by van Viersen and Prescher 2010: fig. 7) does not enable a sufficiently detailed comparison with new species but they appear to share similar sculpture on the glabella but differ especially in the more prominent vaulting of the cranidium, wider preglabellar furrow and more prominent tropidium. Astycoryphe arduinnae vAN VIERSEN, van Rossum et Prescher, 2012 differs from A. tureki sp. nov. in particular in the medially discontinuous tropidium and different ornamentation of the glabella but in common has faintly impressed S1-S3 and wider outline of the glabella. Astycoryphe planifrons FEIST, 2003 differs from the new species in the "the extremely weak relief unique among all hitherto known species of Astycoryphe that have generally upraised border rims and a shorter glabella" (Feist 2003: 437 ), by tr. narrower outline of the glabella and by the absence of pits on the preglabellar field.

O c currence. UDI, sample TM 12.

Family Proetidae Hawle et CoRda, 1847

\section{Proetidae indet.}

Pl. 2, Figs 22, 23

M a t e ri a l. One fragment of librigena (PCZCU 2291) and one fragment of cranidium (PCZCU 2295).

Remarks. The studied and figured fragment of librigena is unfortunately so fragmentary that it does not enable any exact affiliation. It is tr. vaulted in cross-section, with a wide inflated anterolateral margin possessing 4-5 fine ridges; the anteriormost three are almost sub-parallel with the margin, the remaining two have a rather irregularly undulating course. The anterolateral border furrow is wide, moderately deep, rather discontinuous, interrupted by inconspicuous finger-like anterolateral projections of the librigenal field. No traces of tropidium on the librigenal field. The eyes (broken off) are large, a sub-ocular groove is present. The surface of the free cheek is smooth, posterolateral border (mostly broken off) with fine short striation sub-parallel with the posterior border.

O c c urren ce. UDI, sample TM 12.

\section{Conclusion}

Although poorly preserved, the brachiopods and trilobites from the 'upper dark interval' in the Koněprusy area represent a new fossil assemblage in the Barrandian area. Along with some taxa known from the subjacent Acanthopyge Limestone (Leptaenopyxis, Quasidavidsonia, Carinatina), some typical upper Eifelian taxa (Protodouvillina, Poloniproductus, Mystrophora, Pentamerella) are reported for the first time from the Barrandian area. Among them, the productide brachiopod Poloniproductus varians is stratigraphically important for the Eifelian-Givetian boundary interval. It is not only the commonest brachiopod in the recently observed assemblage but this species, together with Protodouvillina cf. interstialis, also indicates faunal exchanges with the Rhenish-type fauna. Unlike the commonest brachiopod fauna of the Acanthopyge Limestone summarized by Havlíček and Kukal (1990), the new fauna bear more strophomenides, a productide, a chonetidine and only a few smooth spire-bearing smoothshelled biconvex or coarsely costate brachiopods. The rare occurrence of Astycoryphe tureki sp. n. supports the observations based on brachiopods - it clearly belongs to the A. exilis group typical for the uppermost Eifelian strata from Ardennes and indicates immigration of at least some Rhenish-type trilobite taxa. 


\section{Acknowledgements}

This work was supported by grant GAP210/12/2018 (to M. Mergl) from the Czech Science Foundation (GA CR). We thank Andrzej Baliński (Polish Academy of Sciences, Warsaw) and Fernando Alvarez (Universidad de Oviedo, Oviedo) for critical comments on the manuscript. This is the contribution to IGCP 652 .

\section{References}

Alberti, G. K. B. (1978): Tentaculites (Dacryoconarida) und Trilobiten aus den Wissenbacher Schiefern und aus dem Ballerbacher Kalk (Devon, Rheinisches Schiefergebirge). - Neues Jahrbuch für Geologie und Paläontologie, Monatshefte, 1978(5): 257-266.

Alberti G. K. B. (1979): Zur Dacryoconariden- (Tentakuliten-) Chronologie des herzynischen Unter- und MittelDevons. - Senckenbergiana lethaea, 60: 223-241.

Anderson, M. M., Boucot, A. J., Johnson, J. G. (1969): Eifelian brachiopods from Padaupkin, Northern Shan States, Burma. - Bulletin of the British Museum (Natural History), Geology, 18(4): 107-163.

Baliński, A. (1995): Devonian athyridoid brachiopods with double spiralia. - Acta Palaeontologica Polonica, 40: 129-148.

Barrande, J. (1848): Ueber die Brachiopoden der silurischen Schichten von Böhmen (zweite Abtheilung). - Naturwissenschaftliche Abhandlungen, W. Haidinger, Wien, 2(2): 153-256 + pls XV-XXIII.

Berkyová, S. (2004): Middle Devonian Tentaculitoidea from the late generation of fillings of the neptunian dyke in the Koněprusy area (Prague Basin, Czech Republic). - Journal of the Czech Geological Society, 49: 147-155.

Biernat, G. (1966): Middle Devonian brachiopods of the Bodzentyn Syncline (Holy Cross Mountains, Poland). Palaeontologia Polonica, 17: 1-162.

Biernat, G., Lazarev, S. S. (1988): Genus Poloniproductus nov. (Brachiopoda, Devonian). - Acta Palaeontologica Polonica, 33(1): 59-71.

Boucot, A. J. (1959): A new family and genus of Silurian orthotetacid brachiopods. - Journal of Paleontology, 33: 25-28.

Boucot, A. J., Johnson, J. G., Staton, R. D. (1964): On some atrypoid, retzioid, and athyridoid brachiopoda. - Journal of Paleontology, 38: 805-822.

Bouček, B. (1964): The Tentaculites of Bohemia. - Academia, Praha, 215 pp.

Bouček, B., Prantl, F. (1959): Význam tentakulitů pro stratigrafii středočeského devonu [Significance of tentaculites for stratigraphy of Central Bohemian Devonian]. - Časopis Národního muzea, řada prŕrodovědná, 128: 5-7. (in Czech)

Buch, L. von (1840): Beiträge zur Bestimmung der Gebirgsformationen in Russland. - Archiv für Mineralogie, Geognosie, Bergbau und Hüttenkunde, 15: 3-128. [published again in Ewald, J., Roth, J., Dames, W. (eds) (1885): Leopold von Buch's gesammelte Schriften, vol. 4, no. 2. Reimer, Berlin, pp. 566-656.]

Budil, P. (1995): Demonstration of the Kačák event (Middle Devonian, uppermost Eifelian) at some Barrandian localities. - Věstník Českého geologického ústavu, 70(4): 1-24.

Caster, K. E. (1939): A Devonian fauna from Colombia. Bulletin of American Paleontology, 24: 1-218.

Chlupáč, I. (1998). Devonian. - In: Chlupáč, I., Havlíček, V., Kříž, J., Kukal, Z., Štorch, P. (eds), Palaeozoic of the Barrandian (Cambrian to Devonian). Czech Geological Survey, Prague, pp. 101-133.

Chlupáć, I. (2003): Comments on facies development and stratigraphy of the Devonian, Barrandian area, Czech Republic. - Bulletin of Geosciences, 78(4): 299-312.

Chlupáč, I., Turek, V. (1983): Devonian goniatites from the Barrandian area, Czechoslovakia. - Rozpravy Ústředního ústavu geologického, 46: 1-159.

Conrad, T. A. (1841): Fifth Annual Report on the paleontology of the state of New York. - New York Geological Survey Annual Report, 5: 25-57.

Conrad, T. A. (1842): Observations on the Silurian and Devonian systems of the United States with descriptions of new organic remains. - Journal of the Academy of Natural Sciences of Philadelphia, 8: 228-280.

Copper, P. (1978): Devonian atrypids from western and northern Canada. - Geological Association of Canada Special Papers 18: 289-331.

Copper, P. (1996): Davidsonia and Rugodavidsonia (new genus), cryptic Devonian atrypid brachiopods from Europe and South China. - Journal of Paleontology, 70: 588-602. https://doi.org/10.1017/S0022336000023556

Davidson, T. (1881): On genera and species of spiral-bearing Brachiopoda from specimens developed by Rev. Norman Glass: with notes on the results obtained by Mr. George Maw from extensive washing of the Wenlock and Ludlow shales of Shropshire. - Geological Magazine, new series, Decade II, 8(1): 1-13. https://doi.org/10.1017/S0016756800112993

Duméril, A. M. C. (1806): Zoologie analytique ou méthode naturelle de classification des animaux. - Allais, Paris, xxiv +344 pp.

Feist, R. (2003): Biostratigraphy of Devonian tropidocoryphid trilobites from the Montagne Noire (southern France). - Bulletin of Geosciences, 78(4): 431-446.

Fortey, R. A., Owens, R. M. (1975): Proetida - a new order of trilobites. - Fossils and Strata, 4: 227-239.

Fredericks, G. (1924): Ussuriiskii verkhnii paleozoi. I. Brachiopoda [Upper Palaeozoic of the Ussuriland, I. Brachiopoda]. - Materialy po geologii i poleznym iskopaemym Dal'nego Vostoka, 28: 1-53. (in Russian)

Galle, A. (1994): Rugose corals of the Acanthopyge Limestone of Koněprusy (Middle Devonian, Barrandian, Czech Republic). - Věstník Českého geologického ústavu, 69: 41-58.

Galle, A., Hladil, J. (eds) (1991): Excursion B3: Lower Paleozoic corals of Bohemia and Moravia (Excursion - Guidebook - VI. International Symposium on Fossil Cnidaria including Archeaeocyatha and Porifera). International association for the study of fossil Cnidaria and Porifera, Münster, $83 \mathrm{pp}$.

Girty, G. H. (1904): New molluscan genera from the Carboniferous. - United States National Museum Proceedings, 27: 721-736. https://doi.org/10.5479/si.00963801.27-1372.721 
Gourvennec, R. (1994): Précisions nouvelles sur le genre Reticulariopsis Fredericks, 1916 (Brachiopoda, Spiriferida). - Annales de la Société géologique du Nord, séries 2, 3: 123-131.

Gürich, G. (1896): Das Palaeozoicum im polnischen Mittelgebirge. - Verhandlungen der Russisch-Kaiserlichen Mineralogischen Gesellschaft zu St. Petersbourg, Ser. 2, 32: 1-539.

Halamski, A. T. (2009): Middle Devonian Brachiopods from the northern Part of the Holy Cross Mountains, Poland in relation to selected coeval faunas. - Palaeontographica, Abtailung A, 287: 1-98. https://doi.org/10.1127/pala/287/2009/41

Halamski, A. T., Baliński, A. (2013): Middle Devonian brachiopods from the Southern Maïder (Eastern AntiAtlas, Morocco). - Annales Societatis Geologorum Poloniae, 83: 243-307.

Hall, J. (1843): Natural History of New York. Geology of New York, part 4. Comprising the Survey of the fourth Geological District. - Carroll and Cook, Albany, 683 pp.

Hall, J. (1857): Descriptions of new species of Paleozoic fossils from the Lower Helderberg, Oriskany Sandstone, Upper Helderberg, Hamilton and Chemung Groups. - In: $10^{\text {th }}$ Annual Report, New York State Cabinet of Natural History, Albany, pp. 41-186.

Hall, J. (1867): Natural History of New York. Palaeontology, vol. IV, part I: Descriptions and figures of fossil Brachiopoda of the Upper Helderburg, Hamilton, Portage and Chemung Groups. - Geological Survey of New York, Albany, 428 pp.

Hall, J., Clarke, J. M. (1894): Natural History of New York. Palaeontology, vol. VIII: An introduction to the study of the genera of Palaeozoic Brachiopoda, part II. - Geological Survey of the State of New York, Albany, xvi + 394 pp.

Harper, C. W., Jr., Boucot, A. J. (1978): The Stropheodontacea, Part II: Douvillinidae, Telaeoshaleriidae, Amphistrophiidae and Shaleriidae. - Palaeontographica, Abteilung A, 161: 119-175.

Harper, D. A. T., Alvarez, F., Boucot, A. J., Williams, A., Wright, A. D., Schemm-Gregory, M. (2010): Tropidoleptida (Brachiopoda): Devonian hopeful monsters or misplaced orphans. - Special Papers in Palaeontology, 84: 119-136.

Havlíček, V. (1963): Family Leptaenidae (Brachiopoda) im Böhmischen Altpaläozoikum. - Časopis Národního muzea, 82: 220-225.

Havlíček, V. (1967): Brachiopoda of the suborder Strophomenidina in Czechoslovakia. - Rozpravy Ústředního ústavu geologického, 33: 1-235.

Havlíček, V. (1987): Lower Devonian and Eifelian Atrypacea (Brachiopoda) in central Bohemia. - Sborník geologických věd, Paleontologie, 28: 61-115.

Havlíček, V., Kukal, Z. (1990): Sedimentology, benthic communities, and brachiopods in the Suchomasty (Dalejan) and Acanthopyge (Eifelian) limestones of the Koněprusy area (Czechoslovakia). - Sborník geologických věd, Paleontologie, 31: 105-205.

Havlíček, V., Racheboeuf, P. R. (1979): Chonetacea (Brachiopodes) du Silurien et du Dévonien de Bohême (Tchécoslovaquie). - Annales de Paléontologie, Invertébrés, 65: 69-138.
Hawle, I., Corda, A. J. C. (1847): Prodrom einer Monographie der böhmischen Trilobiten. - Abhandlungen der königlichen böhmischen Gesellschaft der Wissenschaften, Prag, 5(5): 117-292.

Hladil, J. (1993): Tabulatomorphs and stromatoporoids below and above the upper boundary of the Acanthopyge Limestone (Eifelian/Givetian transition interval, Central Bohemia). - Věstník Českého geologického ústavu, 68: 27-42.

Hladil, J., Beroušek, P., Lukeš, P. (1993): Temné vápencové vrstvy při stropu akantopygových vápenců u Koněprus - otomari-Kačák event [Dark limestone beds near top of the Acanthopyge Limestone at Koněprusy - otomari-Kačák Event]. - Zprávy o geologických výzkumech v roce 1991: 53-55. (in Czech)

Hladil, J. Galle, A., Zikmundová, J., Kalvoda, J., Beroušek, P. (1991): Stop B3-4, Acanthopyge Limestone of the Koněprusy area. Červený lom, Preisslerův lom and Jiráskův lom. - In: Galle, A., Hladil, J. (eds), Excursion B3: Lower Paleozoic corals of Bohemia and Moravia (Excursion - Guidebook - VI. International Symposium on Fossil Cnidaria including Archaeocyatha and Porifera). International association for the study of fossil Cnidaria and Porifera, Münster, pp. 20-23, 26-29.

Jansen, U. (2001): Morphologie, Taxonomie und Phylogenie unterdevonischen Brachiopoden aus der Dra-Ebene (Marocco, PräSahara) und dem Rheinischen Schieferegebirge (Deutschland). - Abhandlungen der Senckenbergischen Naturforschenden Gesselschaft, 554: 1-389.

Johnson, J. G. (1966): Middle Devonian brachiopods from the Roberts Mountains, central Nevada. - Palaeontology, 9: 152-181.

Kalvoda, J. (1992): The youngest conodont fauna of the Barrandian. - Scripta, Geology, 22: 61-63.

Kayser, E. (1871): Die Brachiopoden des Mittel- und Ober-Devon der Eifel. - Zeitschrift der deutschen geologischen Gesellschaft, 23: 491-647.

Khodalevich, A. N., Breivel, I. A., Breivel, M. G., Vaganova, T. I., Torbakova, A. F. (1959): Brakhiopody i korally iz Eifelskikh boksitonosnykh otlozheniy vostochnogo sklona srednego i severnogo Urala [Brachiopods and corals from the Eifelian bauxite-bearing deposits of the eastern slope of the central and northern Urals]. Ural'skoe Geologicheskoe Upravlenie, Gosgeoltekhizdat, Moscow, 283 pp. (in Russian)

King, W. (1846): Remarks on certain genera belonging to the class Palliobranchiata. - Annals and Magazine of Natural History, ser. 1, 18: 26-42. https://doi.org/10.1080/037454809494387

King, W. (1850): A Monograph of the Permian Fossils of England. - Monograph, Palaeontographical Society, London, 3(5): xxxviii $+258 \mathrm{pp}$. https://doi.org/10.5962/bhl.title. 114608

Mergl, M. (2019): Lingulate brachiopods across the Kačák Event and Eifelian-Givetian boundary in the Barrandian area, Czech Republic. - Bulletin of Geosciences, 94(2): 169-186. https://doi.org/10.3140/bull.geosci.1740

Mergl, M., Vaškaninová, V., Žigaite, Ž. (2017): Vertebrate microremains from the Pragian, Emsian and Eifelian of the Prague Basin (Czech Republic). - Folia musei rerum 
naturalium Bohemiae occidentalis, Geologica et Paleobiologica, 51(1-2): 1-12.

https://doi.org/10.1515/fbgp-2017-0001

Modzalevskaya, T. L. (1979): K sistematike paleozoiskikh atiridid [Systematics of Palaeozoic athyridids]. - Paleontologicheskiy Zhurnal, 1979: 48-63. (in Russian)

Moore, R. C. (1952): Brachiopods. - In: Moore, R. C., Lalicker, C. G., Fischer, A. G. (eds), Invertebrate fossils. McGraw-Hill, New York, pp. 197-267.

Muir-Wood, H. M. (1955): A History of the Classification of the Phylum Brachiopoda. - British Museum (Natural History), London, $\mathrm{v}+124 \mathrm{pp}$.

Muir-Wood, H. M. (1962): On the Morphology and Classification of the brachiopod suborder Chonetoidea. - British Museum (Natural History), London, viii + 132 pp.

Muir-Wood, H. M., Cooper, G. A. (1960): Morphology, classification and life habits of the Productoidea (Brachiopoda). - Geological Society of America Memoir, 81: $1-447$.

https://doi.org/10.1130/MEM81-p1

Nalivkin, D. V. (1930): Brakhiopody verkhnego i srednego Devona Turkestana [Brachiopods of the Upper and Middle Devonian of Turkestan]. - Trudy Geologicheskogo Komiteta, 180: 1-221. (in Russian)

Obrhel, J. (1961): Die Flora der Srbsko-Schichten (Givet) des mittelböhmischen Devons. - Sborník Ústředního ústavu geologického, Oddíl paleontologický, 26: 7-46.

Obrhel, J. (1968): Die Silur und Devonflora des Barrandiums. - Paläontologische Abhandlungen, Abteilung B, 2(4): 635-703.

Öpik, A. A. (1934): Über die Klitamboniten. - Tartu Ulikooli Geoloogia Instituudi Toimestuesed Acta et Commentationes Universitatis Tartuensis, 39: 1-239.

Phillips, J. (1841): Figures and descriptions of the Palaeozoic fossils of Cornwall, Devon, and west Somerset. Geological Survey of Great Britain, Memoir 1. Longman et Co., London, xii + 231 pp.

Poulsen, C. (1943): The fauna of the Offley Island Formation, Part II, Brachiopoda. - Meddelelser om Grønland, 72: $1-60$.

Přibyl, A. (1946): Příspěvek k poznání českých proetidů (Trilobitae) [Contribution to knowledge of Bohemian proetids (Trilobita)]. - Rozpravy Československé akademie věd, Řada matematicko-přírodovědných věd, 55(10): 1-37. (in Czech)

Quenstedt, F. A. (1871): Die Brachiopoden. - In: Petrefactenkunde Deutschlands, vol. 2(1). Fuess, Leipzig, 748 pp.

Racheboeuf, P. R. (1981): Chonetacés (Brachiopodes) siluriens et dévoniens du Sud-Ouest de l'Europe. - Mémoire de la Société Géologique et Minéralogique de Bretagne, 27: 1-294.

Richter, R., Richter, E., (1919): Der Proetidenzweig Astycoryphe - Tropidocoryphe - Pteroparia. - Senckenbergiana, 1: 1-17, 25-51.

Roemer, C. F. (1844): Das Rheinische Übergangsgebirge, Eine palaeontologisch-geognostische Darstellung. - Verlag der Hahn'schen Hofbuchhandlung, Hannover, 97 pp.

Rzhonsnitskaya, M. A. (1956): Nadsemeystvo Pentameracea M'Coy [Superfamily Pentameracea M'Coy, 1844]. - In: Kiparisova, L. D., Markovskiy, V. P., Radchenko,
G. P. (eds), Materialy po paleontologii, novye semeystva i rody. - Vsesoyuznyy Nauchno-Issledovatel'skiy Geologicheskiy Institut (VSEGEI), novaya seriya, 12: 49-50. (in Russian)

Rzhonsnitskaya, M. A. (1960): Otryad Atrypida. - In: Sarytcheva, T. G., Orlov, Y. A. (eds), Mshanki, Brakhiopody [Bryozoa, Brachiopoda] (Osnovy paleontologii, vol. 7). - Akademia Nauk SSSR, Moscow, pp. 257-264. (in Russian)

Rzhonsnitskaya, M. A. (1975): Biostratigrafiya Devona okrayin Kuznetskogo Basseyna, Tom 2, Opisanie brakhiopod, Chast' 1, Pentamerida i Atrypida [Biostratigraphy of the Devonian in margins of the Kuzneck Basin, Volume 2, Description of Brachiopods, Part 1, Pentamerida and Atrypida]. - Trudy, Vsesoyuznyy Nauchno-Issledovatel'skiy Geologicheskiy Institut, novaya seria, 244: 1-232. (in Russian)

Sapelnikov, V. P. (1973): Novye taksonomicheskie gruppy v otriade Pentamerida (Brakhiopody) [New taxonomic groups in the order Pentamerida (Brachiopods)]. - In: Ezhegodnik, 1972. Institut Geologii i Geokhimii, Uralskiy Nauchnyy Tsentr, Akademia Nauk SSSR, Sverdlovsk, pp. 39-41. (in Russian)

Sarytcheva, T. G., Sokolskaya, A. N. (1959): O klassifikatsiyi lozhnoporistykh brakhiopod [On the classification of pseudopunctate brachiopods]. - Doklady, Akademiya Nauk SSSR, Moscow, 125: 181-184. (in Russian)

Schlotheim, E. F. von (1820-1823): Die Petrefactenkunde auf ihrem jetzigen Standpunkte durch die Beschreibung einer Sammlung versteinerter und fossiler Überreste des Thier- und Pflanzenreichs der Vorwelt erläutert. Bekker'schen edit., Gotha, 726 pp.

Schmidt, W. E. (1913): Cultrijugatuszone und Unteres Mitteldevon südlich der Attendorn-Elsper Doppelmunde. Jahrbuch der Preussischen Geologischen Landesanstalt zu Berlin, 33: 263-318.

Schnur, J. (1854): Zusammenstellung und Beschreibung sämmtlicher im Übergangsgebirge der Eifel vorkommenden Brachiopoden. - Palaeontographica, 3: 169-254.

Schuchert, C. (1893): Classification of the Brachiopoda. American Geologist, 11: 141-167.

Schuchert, C. (1913): Class 2. Brachiopoda. - In: Zittel, K. A. von, Text-book of Palaeontology, vol. 1, part 1, $2^{\text {nd }}$ ed. MacMillan et Co., Ltd., London, pp. 355-420.

Schuchert, C., Cooper, G. A. (1931): Synopsis of the brachiopod genera of the suborders Orthoidea and Pentameroidea, with notes on the Telotremata. - American Journal of Science, series 5, 22: 241-255. https://doi.org/10.2475/ajs.s5-22.129.241

Schuchert, C., Cooper, G. A. (1932): Brachiopod genera of the suborders Orthoidea and Pentameroidea. - Memoirs of the Peabody Museum of Natural History, 4: i-xii + $1-270$. https://doi.org/10.5962/bhl.title.5732

Siebold, C. T. von (1848): Lehrbuch der vergleichenden Anatomie der Wirbellosen Thiere. - In: von Siebold, C. T., Stannius, H., Lehrbuch der vergleichenden Anatomie. Verlag von Veit and Company, Berlin, pp. 1-679. https://doi.org/10.5962/bhl.title.118645

Siehl, A. (1962): Der Greifensteiner Kalk (Eiflium, Rheinisches Schiefergebirge) und seine Brachiopoden- 
fauna, 1: Geologie, Atrypacea und Rostrospiracea. Palaeontographica, Abteilung A, 119: 173-221.

Spriestersbach, J. (1925): Die Oberkoblenzschichten des Bergischen Landes und Sauerlandes. - Jahrbuch der Königlich Preussischen Geologischen Landesanstalt zu Berlin, 45: 367-450.

Stehli, F. G. (1954): Lower Leonardian Brachiopoda of the Sierra Diablo. - Bulletin of the American Museum of Natural History, 105: 257-358.

Størmer, L. (1944): On the relationships and phylogeny of fossil and recent Arachnomorpha. - Skrifter Utgitt av det Norske Videnskaps-Akademi i Oslo, I. Matematisk-Naturvetenskapelig Klasse, 1944(5): 1-158.

Struve, W. (1964): Mimatrypa, n. g. (Atrypidae: Palaferellinae). - Senckenbergiana lethaea, 45: 433-440.

Svoboda, J., Prantl, F. (1950): On the stratigraphy and tectonics of the Lower Paleozoic around Koda near Srbsko (Central Bohemia). - Sborník Státního geologického ústavu Československé republiky, oddíl geologický, 17: 393-436.

Viersen, A. P. van, Prescher, H. (2010): Taxonomy and biostratigraphy of some proetid trilobites in the Middle Devonian of the Ardennes and Eifel (Rhenohercynian Zone). - Bulletin de l'Institut royal des Sciences naturelles de Belgique, Sciences de la Terre, 80: 5-45.

Viersen, A. P. van, Rossum, A. van, Prescher, H. (2012): New data on Astycoryphe, Dohmiella, Longiproetus and Quadratoproetus (Trilobita, Proetidae) from the Middle Devonian in the Ardennes, Belgium. - Neues Jahrbuch für Geologie und Paläontologie, Abhandlungen, 264(1): 77-87.

https://doi.org/10.1127/0077-7749/2012/0233
Waagen, W. H. (1883). Salt Range Fossils, I. Productus-Limestone Fossils: iv. Brachiopoda, fasc. 2.-Memoirs of the Geologogical Survey of India, Palaeontologia Indica, series 13, pp. 391-546.

Waagen, W. H. (1884): Salt Range Fossils, I. Productus-Limestone Fossils: iv. Brachiopoda, fasc. 3+4. Memoirs of the Geological Survey of India, Palaeontologia Indica, series 13, pp. 547-728.

Walch, J. E. I. (1771): Die Naturgeschichte der Versteinerungen zur Erläuterung der Knorrischen Sammlung von Merkwürdigkeiten der Natur. Dritter Theil. - Felßecker, Nürnberg, $235 \mathrm{pp}$.

Walcott, C. D. (1884): Paleontology of the Eureka district, Nevada. - Monograph, United States Geological Survey, 8: 1-298. https://doi.org/10.5962/bhl.title.23478

Williams, A., Carlson, S. J., Brunton, C. H. C., Holmer, L., Popov, L. E. (1996): A supra-ordinal classification of the Brachiopoda. - Philosophical Transactions of the Royal Society, Biological Science, 355: 1171-1193. https://doi.org/10.1098/rstb.1996.0101

Zikmundová, J., Kalvoda, J. (1991): Provisional list of conodonts. - In: Galle, A., Hladil, J. (eds), Excursion B3: Lower Paleozoic corals of Bohemia and Moravia (Excursion - Guidebook - VI. International Symposium on Fossil Cnidaria including Archaeocyatha and Porifera). International association for the study of fossil Cnidaria and Porifera, Münster, pp. 24-25. 


\section{Explanations of plates}

\section{PLATE 1}

Protodouvillina cf. interstrialis (PHILliPs, 1841)

1. Ventral valve showing exterior (b), details of the apex (a) and ornamentation (c); PCZCU 2261.

2. Fragment of ventral valve; PCZCU 2263.

3. Fragment of ventral valve showing multicostellate ornamentation; PCZCU 2262.

Douvillinella sp.

4. Incomplete dorsal valve interior; PCZCU 2264.

Leptaenopyxis (?) sp.

5. Small ventral valve, external (a) and internal (b) moulds; PCZCU 2265.

Poloniproductus varians (BIERNAT, 1966)

6. Small ventral valve (a) and in oblique view (b); PCZCU 2266.

7. Dorsal valve external mould (a) and in oblique view (b); PCZCU 2267.

8. Ventral valve (a) and in anterolateral view (b) and detail of surface (c); PCZCU 2268.

9. Deformed ventral valve partly preserved as internal mould showing fine pustules; PCZCU2269a.

10. External mould of juvenile dorsal valve, PCZCU 2270.

11. Detail of hinge line of dorsal valve, external mould; PCZCU 2294

Iridistrophia sp.

12. Ventral valve (a), and detail of ornamentation on left (b) and anterior (c) margins; PCZCU 2269b.

13. Internal mould of small ventral valve; PCZCU 2271.

All: Eifelian/Givetian boundary interval, 'upper dark interval', Polygnathus ensensis Zone. Locality: Koněprusy, Jirásek's Quarry, new section. Scale bar $=1 \mathrm{~mm}$.

\section{PLATE 2}

Holynetes cf. holynensis HavlíčeK et Racheboeuf, 1995

1. Dorsal valve (a) and its external mould (b); PCZCU 2272.

2. Ventral valve, partly exfoliated; PCZCU 2273.

Mystrophora sp.

3. Dorsal valve; PCZCU 2274.

Pentamerella sp.

4. Dorsal valve (a) and in oblique view (b); PCZCU 2275.

5. Ventral valve; PCZCU 2276.

Carinatina (?) sp.

6. Ventral valve internal mould; PCZCU 2277.

7. Dorsal valve external mould; PCZCU 2278.

18. External mould showing high ventral interarea; PCZCU 2288.

Carinatina arimaspus (EICHWALd in von Buch, 1840)

8. Ventral valve, incomplete internal mould; PCZCU 2279.

9. Incomplete ventral valve; PCZCU 2280.

14. Detail of external microornament; PCZCU 2293.

Mimatrypa (?) sp.

10. Deformed ventral (?) valve; PCZCU 2281.

Leptathyris sp.

11. Ventral valve; PCZCU 2282.

12. Ventral valve, partly exfoliated; PCZCU 2283.

13. Ventral valve of complete articulated specimen; PCZCU 2284.

Quasidavidsonia mediocarinata (HAvLíčEK, 1967)

15. Dorsal valve; PCZCU 2285.

Eoreticularia sp.

16. Exfoliated dorsal valve; PCZCU 2286.

17. Exfoliated dorsal valve; PCZCU 2287.

Astycoryphe tureki sp. nov.

19. Fragment of thoracic segment, only questionably affiliated to the new species; PCZCU 2292.

20. Paratype, librigena; PCZCU 2289.

21. Holotype, cranidium in dorsal (a) and oblique (b) views; PCZCU 2290.

Proetidae indet.

22. Librigena; PCZCU 2291.

23. Incomplete cranidium; PCZCU 2295.

All: Eifelian/Givetian boundary interval, 'upper dark interval', Polygnathus ensensis Zone. Locality: Koněprusy, Jirásek's Quarry, new section. Scale bar $=1 \mathrm{~mm}$. 
PLATE 1

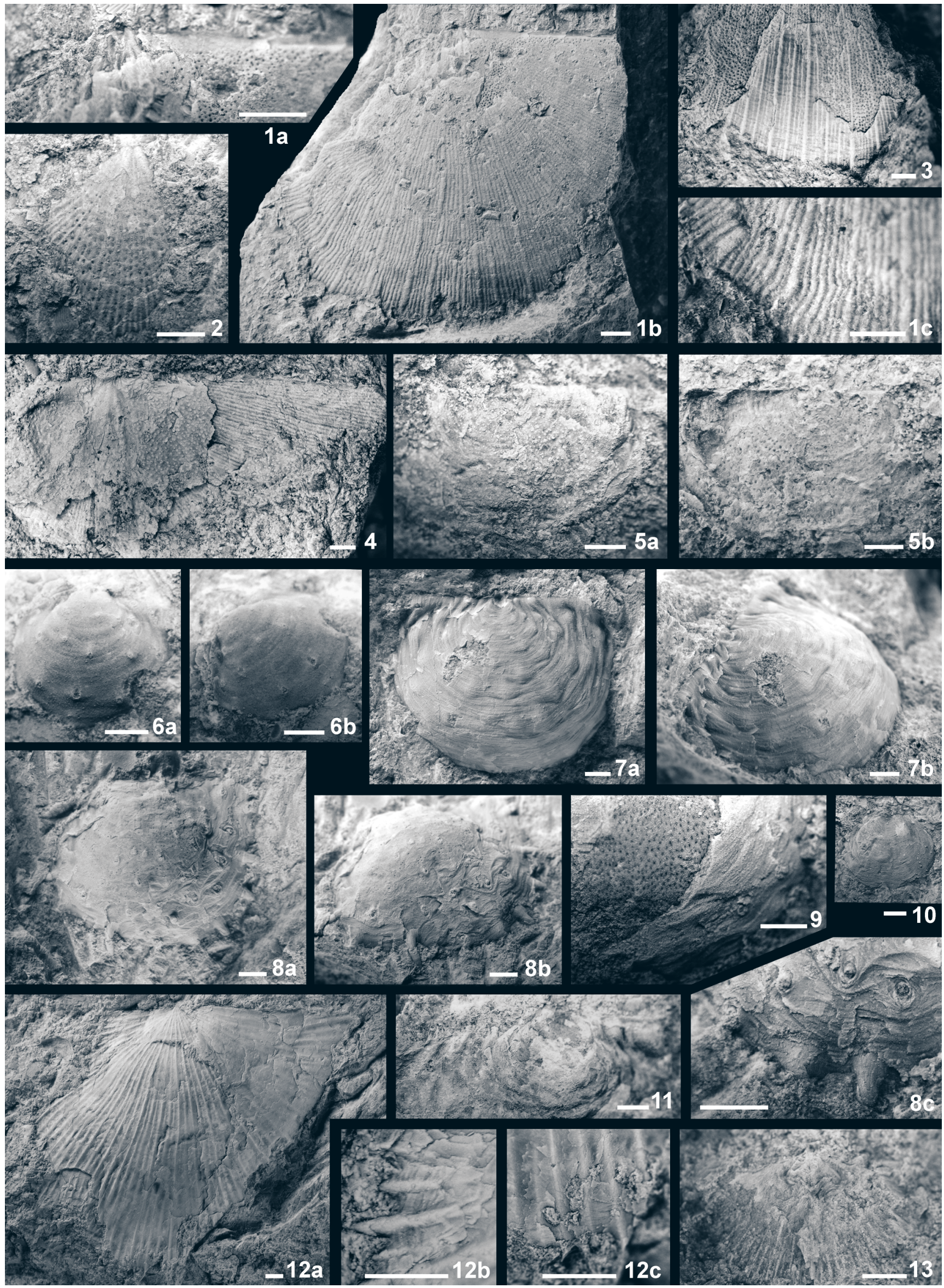




\section{PLATE 2}

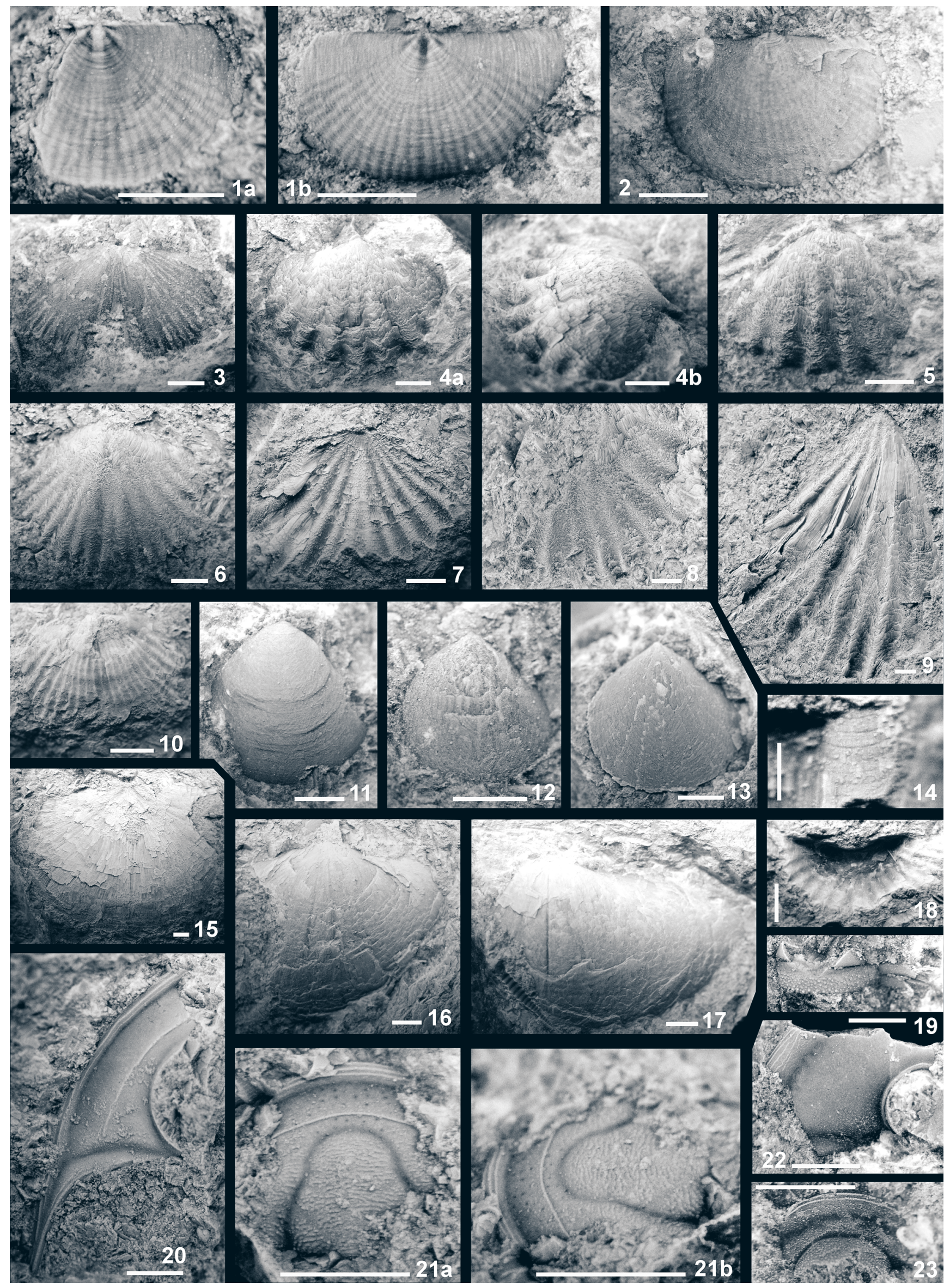

